\title{
Nala and Countryside Tourism
}

\author{
Biswo Nath Ulak*
}

\begin{abstract}
The behaviour of tourists in modern time shows an urgent need to promote countryside tourist destinations in Nepal. Tourism supply needs to be integrated and well coordinated, including all necessary amenities for an enjoyable stay similar to the rural village tourism at Ghandruk, Sarankot, Chitwan etc. at different part of Nepal. More marketing efforts should be made to attract target markets of tourists.

Rural tourism, including agritourism, can play an important role to change the fate of Nala in Kavrepalanchowk District. Nala at present is facing the problem of unemployment and deterioration of natural and cultural qualities. The social and ecological aspect is of great importance rather than economic one. Proper development of such areas should be multidirectional. The increasing interest of domestic as well as international tourist in the villages with countryside tour has created a possibility of establishing Nala as a new destination of Countryside Tourism. These new initiations not only saves one of the historically important village ecologically and culturally but also pave the way for the development of entire community of villages providing new employment opportunity and mobilizing the local resources as well.
\end{abstract}

The aim of this research work is to explore the opportunity of developing countryside tourism in Nala village with taming exclusive environmental and cultural values, as well as to present its role in the development of tourism in Nepal.

Keywords: countryside tourism, new tourist destination, rural tourism, exclusive environmental values

\section{Introduction}

The Cambridge dictionary defines 'countryside' as 'the land, which is not in towns, cities, or industrial areas, that is either used for farming or left in its natural condition'. The human settlements near by a town or city are known as countryside. There is a typical name for such settlement as "Kanth" in Nepali language. And in English an inhabitant of a rural area is known as a countryman. .

Tourists to Nepal are lured by the captivating sights and experiences, incredible mountains, and ancient cultures and religions. Nepal is an ecological dreamland, rich in

\footnotetext{
* Biswo Ulak has done Master in Political Science from Tribhuvan University, Kathmandu Nepal
} 
biodiversity. The hills of Nepal are home to a diverse array of ethnic caste groups. To visit Nepal is to see "life in a land without wheels" (Kunwar, 1997, p. 201). To better harness Nepal's unlimited tourism potential, tourism products around social and cultural events could be developed in newer areas such as adventure spots. The tourism products that are available in Nepal are not exploited optimally for the benefit of tourists or tourism operators. There are opportunities for tourism operators and local and national beneficiaries to develop new and innovative models of tourism to deliver more and more equally distributed benefits.

\section{The Government of Nepal has formulated its Tourism Vision 2020 as:}

Tourism is valued as the major contributor to a sustainable Nepal economy, having developed as an attractive, safe, exciting and unique destination through conservation and promotion, leading to equitable distribution of tourism benefits and greater harmony in society (MoTCA, 2009, p.5).

The unique geographical setting and outstanding natural beauty has created exceptional tourist attractions to Nepal. The potential to attract tourists into new areas is associated with the long- haul market. The Tourism Industry now demands more meaningful involvement and more responsible and sustainable tourism practices. After the political change of 1990, the local communities, Non Government Organizations and Private Sectors, had been raising very important voice in the way in which tourism is/can developed and, resources mobilization. The tourism sector is as significant to Nepal economy as the Water Resources and Natural Resources (forest) are the Nepal economy. It is more effective and sustainable growth if the responsible authorities including Government of Nepal develop and promote this business. Tourism provides entrepreneurial opportunities to small operators fostering balanced development and empowering rural communities, youth and women, and can dynamics other sectors of the economy, particularly the agriculture sector.

Countryside tourism includes touring rural areas and visiting country-towns and villages, seeking out the experiences and products they have on offer. It is the point of juncture between rural tourism and other forms of tourist activity in rural areas. The central defining characteristic remains the primary interest of the tourist in the rural character of place. There are many landscapes and culture activities available in Nepal suitable to rural and countryside tourism.

Countryside tourism in Nepal is broad enough to include non-farm based offerings, such as bed and breakfast, local museums, local cultures, bhattis (local pubs) and restaurants, arts and crafts, rural tours, and the various types of farm stay where the degree of dependence on tourism, and hence the extent to which the product can be pitched for tourists, goes beyond the coincidental involvement described with agritourism. The appeal to tourists is wider than that of agritourism or culture tourism and the experiences are a mix of staged and intrinsically authentic. It encapsulates important and experiences in the wider landscape beyond the concentration on farms. The influence of countryside aesthetics is critical. It will conceptually located between agritourism and way of life in village and city, because the experiences are a mix of authentic and staged experiences founded on the rural character of place. There are many countryside towns within the 
Kathmandu valley and outside the Kathmandu valley. These countrysides have specific character and differ from one to the other. However, all the countryside towns are surrounded by rural areas. Nepali people have demonstrated a good hospitality practices in rural areas at Sarankot, Ghandruk, Chitwan etc. under home stay tourism. The lifestyle and culture of countryside towns are specific and unique in Nepal. Promoting the tourism in countryside will be an ample opportunity to the tourist testing/understanding real culture of Nepal. On the other hand, these small settlements can be developed as countryside tourist destination as they have resources and potentialities attracting tourist.

The current favourable political situation in Nepal has provided a strong base for the development of the tourism industry. Restoration of peace from the political change of 2006 and Constitution Assembly Election of 2008 have a central and decisive role to play as a catalyst in promoting responsible and sustainable tourism, while maximising the benefits from tourism through income and employment in rural areas. Tourism can generate major opportunities for Nepal, if managed properly, as demonstrated in the Khumbu region and the Annapurna Conservation Area (Bajracharya, 2009, p.129). The approach of tourism development should be 'people-centered' rather than 'growthoriented' (Sharma, 2009, p.48) as Nepal is facing big unemployment problem. Mobilisation of ideal resources will automatically generate the income and contribute in growth. Tourism business should develop in line with local needs and aspirations, taking into account the conservation of environment, maintenance of culture values, and the need for earnings and employment, while at the same time responding to global threats such as climate change, the energy crisis, food security and the current economic crisis. Because of its proven effectiveness as a tool for socioeconomic transformation, tourism should be the most prioritised sector for poverty reduction.

Nepal Tourism Statistics 2011 of Minister of Culture, Tourism and Civil Aviation (GON) has shows that majority of tourists come for holiday and pleasure is $40.41 \%$, followed by trekking and mountaineering $19.77 \%$. Recently both are in decreasing trend with uncertainty of political instability. The indicator shows, other tourist are growing, this is in mainly unofficial business people in a diplomatic presents in Nepal, seeking for investment opportunities. Similarly, the number of pilgrimage from North India is increasing with their economic booming since last decade (Khatri, 2012, p.19). The aggregate tourist arrival in Nepal is increasing trend of $7.22 \%$ annually, with the fluctuated rates. There was minus (decrease) of $22.1 \%$ in 2001 due to personal insecurity with political uncertainty after Royal Massacre and increased 37.2\% in 2007 after the success of 19 days Jana Andolan II of 2006. The rate of tourist arrival is fluctuating within last 20 years (1990s-2010) mainly due to political situation regarding personal security. The average length of stay of a tourist is 10.99 days. The data shows that the minimum days 7.92 stayed in 2002 and 13.51 days in 2004 (Khatri, 2012, p.7). In the year 2001 the Maoist announced to capture Kathmandu and security was weakened. Otherwise length of stay was satisfactory.

The recent data of UNCTAD shows that Nepal is in 20th rank attracting tourist for their longer stay in this country even with the limited tourist services (http://www.nationsencyclopedia.com/WorldStats/UNCTAD-average-length-stayvisitors.html). The means of attracting tourist in Nepal are: a) peaceful, friendly and 
honest people and b) Himalayas and the diversified natural beauty. A tourist can spend his/her time visiting the heritage sites, making trek to the mountains and villages, participating the local culture from different ethnic groups at different part of country.

Among alternative tour operators, culture and history tours have been popular. However, as awareness and interest in other cultures grows, there is an increasing demand to interact with local communities. More specialized culture tours are offering possibilities to include home stays as part of the cultural tour experience. As part of the trend toward authenticity and interactive holidays, more consumers also want immersion in the language, customs, crafts, cuisine, and other cultural aspects of the region visited.

The cost of travel, their safe accommodation and hygienic food is part of attracting tourist for their longer stay. A tourist can accommodate in Nepal with the daily budget of US\$20. From the view point of tourism, Nepalese cities are considered as cheapest cities in Asia. For example, a tourist will spend US\$ 14.89 in Pokhara and US\$ 17.48 in Kathmandu for a day+night (http://www.priceoftravel.com/2060/asia-backpacker-index). Tourism promotional activities from Nepal are not enough on these.

At present tourism activities are largely concentrated in the Kathmandu Valley, followed by Pokhara, Chitwan National Park and trekking destinations such as the Annapurna Conservation Area, Sagarmatha National Park and Langtang. Tourist activities and their area need to be expanded as well as tourist production also need to be increased for attracting tourist to longer stay introducing countryside tourism.

\section{Methodology}

Research methodology followed in the study is a compound one, comprising historical, descriptive, analytical, empirical, comparative as well as statistical approaches. It encompasses both types of sources of data i.e. secondary as well as primary.

Results of the survey conducted in Nala Village to ascertain the ground realities through recording the views of all stakeholders of tourism in Nala Village including: tourists, locals, hoteliers, and officials of the Ugrachandi Nala Village Development Committee.

Secondary sources of the data collected include; reports of World Tourism Organization, annual reports and year hand book published from time to time from Ministry of Tourism and Civil Aviation of GoN, Tourism Development Board of Nepal, Environmental Sanitation Improvement Plan for Nala, and various books, journals, periodicals, newspapers, websites and others publications referring Nala.

The research employed combination of almost all of the techniques of data collection. Besides own observations, questionnaires were served, structured and semi-structured interviews were conducted with individuals of related field, who influenced the decisionmaking process at different levels and to varying degrees. These target individuals included government officials, tourists, locals, service providers (hoteliers, transporters), experts and intellectuals, journalists and commentators and others, given the relevancy and relativity subject to their availability and access of the researcher. 
The purpose of this study is to explore the natural and cultural heritage treasury hidden in Nala to promote as a countryside tourist place. This assignment has expected to support increasing eco-tourism contributing to economic development as well as awaking local people for conservation natural and cultural heritage of Nala.

\section{Nala}

A small city with varieties of houses remained from Malla Period ${ }^{1}$ to present is the unique village attraction of learning for tourist on human development. Nala lies between $27^{\circ} 39^{\prime}$ to $27^{\circ} 65^{\prime}$ North Latitude and $85^{\circ} 32^{\prime}$ to $85^{\circ} 70^{\prime}$ East longitude and is located at a mean elevation of about 1,400 meters (4,384 feet) above sea level. The climate of Nala village is sub-tropical with maximum of $35.6^{\circ} \mathrm{C}$ in April and minimum of $-3^{\circ} \mathrm{C}$ in January and $75 \%$ annual average humidity. The temperature in general is $19^{\circ} \mathrm{C}$ to $27^{\circ} \mathrm{C}$ in summer and $2{ }^{\circ} \mathrm{C}$ to $20^{\circ} \mathrm{C}$ in winter. The average rainfall is 1400 millimeters, most of rainfall occurs during June to August.

Nala has a clustered settlement under the Ugrachandi VDC (Village Development Committee) of Kavre Palanchowk District of Nepal. The name of VDC derived from the famous goddess 'Ugrachandi Bhagawati' located in Nala village. Physically this village is surrounded by green hills from three sides north, south and west and open fertile land lies to Eastern part and is situated at northwest of Kavrepalanchowk District. The two famous river of village Punyamata and Nanyamata flow at south of Nala. The source of Punyamata is Mahadev Pokhari and its watershed cover an area of $64.039 \mathrm{Km} 2$ (Christain etal., 2005, p.17). This VDC is surrounded by Tukucha Nala VDC, Nasikasthan Sanga VDC, Banepa Municipality, Rabi Opi VDC and Devitar DVC of Kavre District. Nala is at the middle of the fertile agriculture land and situated at foot hills of Nagarkot with 2.5 kilometers far from Tin Dobato (cross road) of Banepa with good motorable road of 10 minutes drive in vehicle. This town is also linked to Chyamasingha, Bhaktapur with a motorable road of 6.72 kilometers of 15 minutes drive. It is 19 kilometers far from Kathmandu. Public transport services (bus) are available from Purano (old) Bus Park of Kathmandu, Chyamasingh of Bhaktapur and Tindobato of Banepa. In term of the location Nala is very accessible ${ }^{2}$ to all categories of visitors. There are several other scattered beautiful settlements that are included in Ugrachandi Nala VDC, they are Bhandari Gaun, Sera, Aangal, Kakre, Suwara, Tusal, Bantal and Chunatal.

There are 1,444 households with the population of 7,198. Of which there are males 3,550 and females 3,648 (CBS statistics 2011). The population is mixed with the Brahmins, Chhetris, Giris, Tamangs, Magars, Sarkis, Damais, Kamis and Newars. Nala Bazar is the core settlement area of Ugrachandi VDC and mainly populated by Newars with different sub-caste groups as: Shrestha, Pujari, Kishi, Bajracharya, Manandhar, Prajapati, Suwal, Napit, Karmacharya, Dhambar, Khadagi, Ranjitkar, Suwal, Kusle, Joshi, Deula, Putuwar, Achaju, Phaiju, Bhan, Yente, Makai, Libichhe, Pamang, Vaidhya, Pradhan, Aanamuni, Chakubaji, Sat Dware etc. The settlement is divided into nine clusters known as Tole

1 There are few video documentary made on Nala can be seen in http://www.youtube.com/watch?v=LA9BgPozUtg

${ }^{2}$ Advise to see the video from internet http://www.youtube.com/watch?v=VnKXAJYBCos. 
they are: Lagan Tole, Epa Tole, Menchhe Tole, Yanpa Tole, Gansa Tole, Bijyapati Tole, Tupicha Tole, Pode Tole, Jugi (Damai) Tole, and Kyopwa Tole

Nala is one of the famous trekking and bi-cycling tourist routes in Nepal travelling from Bhaktapur and Nagarkot to Banepa, Dhulikhel, Panauti and Namobuddha even it has good motorable linked road. It is one of the best countryside as it is just out of world's second polluted tourist city, Kathmandu and between the two ancient heritage urban centers Bhaktapur and Banepa with panoramic scenery tour from Bhaktapur, Nagarkot and Banepa.

The Ugrachandi VDC has two secondary schools and a higher secondary school. They are Chandeswori high school, Lincoln Int'l School and Spring Hill English School and the Siddhartha University. This university is the first Buddhist University in Nepal (but not functining).

\section{History}

Nala is a historical and religious place of Nepal. The proper Nala is located at the foot of Manimaya Hill which is also known as Tapoban ${ }^{3}$. The name of this place presented with Uttrapur in the path (homage) to Ugrachandi Goddess. There is a myth that says King Dirgha Rath ruled in Nagaripur in Satya Yug, the Golden Age. It is also called Nalang and it must have been derived from Kirat as this word Nalang 4 is similar to the other places name in the time of Kirat Period, i.e. Khopring=Khopa (Bhaktapur), Fanpring $=$ Farping etc (Shrestha, 1993, p.19). This place was known as Nalanggram in Lichhavi Period and continued until Malla Period. It was called Naladesh in Malla Period (Regmi, 1979, p.171). However, there is no any evidence how the name of this place was created. Presently, some Newars of Nala interpreted $\mathrm{Na}$ as Water and La as Path, which means water path as Nala is drained by numbers of small rivers and rivulets. History of Nala has been described with different myths in different epoch (Era) of history.

Satya Yuga ${ }^{5}$ (The Golden Age /Era) - The Myth says that there was human settlement in Nala before the evacuation of water from the Kathmandu valley. The settlement was known as Kingdom of Dirgha Rath. King Dirgha Rath was cruel and was severely punished by Sristikanta Lokeswor godess. Later on he was advised to take fasting on the day of each Aasthami at Punyamata River to freedom from punishment and opening his path to heaven. The angels from heaven also used to come for fasting at Punyamata River once a day of Aasthami that falls in autumn season (September).

Treta Yuga (that succeeded Satya Yuga) - There is a cave behind a big stone in Aangla (Rajatar) just opposite to the Brahmayani Temple, north of Nala. It is believed Maharshi Balmiki has had meditation (Tapasya) and wrote the Ramayan Mahakabya, the great

3 Wild and calm place for practicing meditation

4 Dhanabajra Bajracharya also confirmed the word Nalang is derived from Kirat and the settlement should be there from the time of Kirat

5 In Hindu philosophy there is found the 'era' within a cycle of four yugas. known as the Satya Yuga, the Treta Yuga, the Dwapara Yuga, and finally the Kali Yuga 
Hindu epic, residing in this tunnel (Shrestha, 2003, p.47). People believe the name of river "Punyamata" was taken after Balmaki acquired Punya (virtue) after writing Ramayan. There is also Sita's foot print nearby Bhagawati Temple, a proof of settlement in Treta Yuga?

Dwapar Yuga (that succeeded Treta Yuga) - Kirats were one of the supporters of Pandavas in Mahabharat War. There was Kirat settlement around the villages of Nala. There is continuation the Kirat Devi (Ban Devi) puja after the departure of Kirats. The Kirat Devi puja is happening on any Sundays in the month of Poush (December). All the households bring puja (praying items) from their houses and purchase a young she goat raising money. They go to jungle performing the puja with sacrificing the she-goat. Then they took the goat meat and food items they brought from their houses as offering from god (Shrestha, 1993, p.17). There is a stone sculpture of Yudhisthir Maharaj (the eldest brother of Pandava) at the East yard of Ugrachandi Bhagawati. The Kirat culture and sculpture of Yudhisthir supports the evidence of Dwapar Yuga.

It is believed that the South of Nala and West of Thangu were developed in early stage and many fossils were found from ancient time (Karmacharya, 2003, p.30). People of Nala believed that Manjusri travelled through Nala and spent the night at Lhasapas Saraswati 6 at Sudal VDC of Bhaktapur District on her/his way to pay homage to Swayambhu and evacuating the water of Kathmandu valley (Shrestha, 2003, p.22). It is believed that s/he had crossed Tel Pokhari (pond) from the middle, walking on the Pokhari and the Pokhari is known as Pala ${ }^{7}$ Pokhari.

Kali Yuga (Immoral Era/ the Iron Age) - This era started from 6th century (A.D.), Amshuvarma's Period (Levi, 1908, p.16). The history of Nala can be traced from the period of Lichhavi Period. The sculpture of Ugrachandi Bhagawati and Sristikanta Lokeswor were made in the period of Mana Deva and Nerendra Deva accordingly. An ancient Jal Dron (stone water bucket) attached to the wall near the temple of Bhagawati at Nala is still found there at Lagan Tole. An inscription of $36 \mathrm{~cm}$ wide and $7 \mathrm{~cm}$ long is patched in Jal Dron at the stone tap. A date of 118 Jestha Sukla Dashami (in the month of October) is seen in the inscription. The inscription seems to be indicating the inauguration date of water tap. The record belongs to the reign of Shiva Deva II (694 - 705 AD). (Regmi, 1983, p.131).

Malla Regime - Abhaya Malla was succeeded by Jayadeva ${ }^{8}$. According to the Vamshavalis (chronology), his brother, Ananda Malla founded ${ }^{9}$ a new town called Bhaktapur (modern Bhadgaun) and established a new and independent Kingdom there. In addition to Bhaktapur, Ananda Malla founded seven towns in 12th century in the vicinity of well-known temples. These were Banepur (Banepa) near the Charandeshwari

\footnotetext{
6 It is believe this Saraswati came from Lhasa. The question is Saraswati or Manju Shree

7 In Newari, Pala means foot step

8 A manuscript written in 342 Nepal Era (1221 A.D.) during the period of a certain King named Ranasura (Jayadeva), who was a contemporary of Abhaya Malla, has been discovered. It does not mention "Malla" after Ranasura, but describes him as "Parama Bhattaraka Maharaja" in addition to other titles Bendall thinks he was King in a certain area in Nepal. This view appears to be correct.

9 These towns should not founded, may be extended or renovated as there were evidences from Lichhavi period.
} 
temple, Panawati (Panauti) near Prayaga Tirtha, Nala near the temple of Ugrachandi Bhagawati, Dhulikhel near the temple of Narayan, Khadpu near the Swet Bhairab, and Chaukot near Chekor Rishi's hermitage and Sanga near Nasika Pitha. There were 500 households in Nala during Malla regime (Shrestha, 1993, p.6) to be Desh (town) under the Bhaktapur kingdom.

The ruins of Nala fort, situated at a distance of approximately 4 miles from Bhaktapur, can still be seen. In Malla period, a wall had been constructed around the town with seven Dhwakas (the entrance gates). It is the interesting fact that the seven dhwakas (gates) were erected for different purposes. The Layaku (Rajkul) Dhwaka was used for entering and exiting for newly married brides (i.e. wedding procession etc.) and for any gratifying occasions, Baila Dhwaka was used for visiting Sristikanta Lokesrow Bihar for Grihastha Bhikshu (General Buddhist people ) and Kyopo Dhwaka for outgoing sewage system of the city and the Karya Dhwaka was for going out and returning after completion of special assignments/projects, Palpukhu Dhwaka for visiting Tibet for Tantrik Vidya and Business work, Gansa Dhwaka for accepting people from other community (immigrant) and Si Dhwaka was used for funeral procession. Nala was under the kingdom of Bhaktapur, but it was repeatedly subjugated by the Gorkhalis (Bajracharya, 1964, p.20). It was therefore necessary to make arrangements for the security of the town and those dhwakas were very useful controlling movements in Nala. Most of gates have been turned into ruined and one still stands on the northern and north-western sides. Beyond the wall, a moat had been dug on the hills, traces of which are still visible. No such arrangements had been made on the eastern, southern and western sides, which comprised territory ruled by Bhaktapur. However, the territory beyond the northern hills belonged to Kathmandu (Regmi, 1970, p.111). There are many stone and copper plate inscriptions and some leaf plates in Nala. These inscriptions were written for information on public services to ensure complying rule of law. Most of the inscriptions were found in Malla period. Those inscriptions denoted that Nala developed from ancient age (before Malla regime).

There are no other traceable evidences of Lichhavis apart from the sculpture of Ugrachandi Bhagawati, Sristikanta Lokeswor, inscription in Jal Dron and name of a street Libi Chhen in Nala. But there are many evidences from Malla regime - stone made main gate, fort, wall, numbers of stone taps and wells, public squares (Dabalis) and streets paved with baked bricks and carved stones. The drainage system demonstrates the Nala civilization from early age. The Sattals (Inns), Temple, Monastery, Stupas and few houses were made with Bihari style, Pagoda style and modern style. Most of the wooden and stone arts were followed the Malla regime. The wood work in houses, temple, inns, Monastery and Stupas were made with beautiful arts demonstrating the culture and human development. Most of the houses of Malla period were destroyed by the earthquake of 1943 (1990 BS) and the wooden frame and panel of windows, doors and other part of the wooden item from ruined houses were used in their new houses. The mixture of wooden art with modern structure can be seen in Nala city. Some respondents opine that there was a palace ${ }^{10}$ before the Lichhavi period where the Chandeswory School was constructed. 


\section{Culture and Religion}

Nepal is a sacred land, a mosaic of different cultures. This country is mainly the point of convergent of two main religions Hinduism and Buddhism. Buddhism occupies a most eminent position in Nepal in Lichhavi and Malla dynasty. Nala also can not deviate from this phenomenon and presently Christianity has been added. Nala seems to be occupied by Hinduism in the beginning and adopted the Buddhism from the period of Lichhavi and Malla regime. There are famous three goddesses, a) Sristikanta Lokeswara, b) Ugrachandi Bhagawati and c) Mahalaxmi

a) Ugrachandi Bhagawati - In Hinduism, it is believed that Ugranchandi Bhagawati the power of goddess, was appeared in the Earth to kill the demon Mahisashur, King of Evil. People of Nala believe that she was appeared in Nala in Satya Yuga to drive the Indra, King of heaven who was annoying to the angels devoting at Asthami ${ }^{11}$ fasting in Aswin (September) at Punyamata River. People respect on Ugranchandi Bhagawati for a long time.

One of the earliest and most popular Palanchowk Bhagawati temple is situated in the east of Nala. The statue of the Bhagawati was made in $503 \mathrm{AD}$ during the time of king Man Dev the first historical king of Lichhavi period (Levi, 1908, p.39). As the story goes, Mana Dev decided to take time off and meditated at one monastery in Sakhu. His mother commissioned the best artist to make a statue of Bhagwati. The unknown artist first made the masterpiece at Palanchowk Bhagawati. There is a very popular legend that is told repeatedly, about how the four stone masterpieces were done by the same artist. The king's mother was scared with the artist that he would make a replica. Therefore two fingers of the right hand of the artist were chopped off. The artist was not deterred and went on to carve the Nala Bhagawati even without two fingers. Then one of his arms cut off. With the one remaining hand, he carved another version, Shova Bhagawati at Bishnumati. The second arm was chopped off. He then used his feet to carve the Naxal Bhagawati, which originally was called Nawa Sagar Bhagawati. One needs to take a trip to all four sites to authenticate the legend starting with the masterpiece at Palanchowk and the less than mediocre image at Naxal. There seems to be some truth in the legend.

The stone sculpture of goddess Ugrachandi Bhagawati of Nala was installed in a temple. The present four storied pagoda style temple was constructed in the period of King Jagatjyoti Mall of Bhaktapur in Nepal Sambat 741 and completed in Nepal Sambat 767 by Jagat Prakash Mall, the king of Lalitpur. This Temple was renovated in 2002 by French Project and replaced all tiles roof into cooper roof in all four stories. Many goddess devotees had homage to Bhagawati with different materials including a stone pillar and iron peacock from Jitman Pode. It has demonstrated that the community respect to diversity and inclusion accepting the materials from untouchable caste.

There are two types of Bhagawati statutes; a) one made of stone and permanently installed in the four storied temple and b) three made of bronze with gold painted. The bronze statues are transferable and they are as follows, i) cross leg with hands, ii) cross leg without hands and iii) with eighteen hands. These three bronze Bhagawati statues are

\footnotetext{
${ }^{10}$ The palace must before the Lichhavi as there are myth of king from satya yuga. $118^{\text {th }}$ day of lunay month
} 
stored in Dhyo Chhen 12 at Bijyapati Tole. Annually, these three Bhagawati statues will open displayed to public according to their tradition, i) crossed leg without hands on the day after Aksha Tritiya (mid of April), ii) cross leg with hands on the main day (Tika) of Vijaya Dashami (the main festival of Hindu) and iii) the eighteen hands Bhagawati will make round in Nala bazar twice a year first in Ashoj Tritiya (mid September) and second will be in main day (Tika) of Vijaya Dashami. All caste of Nala, i.e. touchable to untouchable will participate in the procession of Bhagawati goddess. Beside those three movable idols each Newari caste has made Bhagawati pictures for their own caste in utensils (in water jug, cooking pot, measuring unit, weapon etc) ${ }^{13}$, they are a) Karmacharya, b) Kishi, c) Pamang, d) Hipho - in sword, e) Bha, f) Dui, g) Jugi, h) Doi, and i) Po. Those items are stored in the senior member's house of their caste (community). Each caste conducts a day puja to their family Bhagawati items with picture in each year. This will be in different days than the main Bhagawati puja and do not clash with each other caste.

b) Karunamaya - Nala people say Sristikanta Lokeswor was appeared in Nala in Satya Yug to punish the then King. They also believed Siddartha Gautam has visited Nala and stayed at Sristikanta Lokesrow for four months while visiting at Namo Buddha. There is a Ashok Chaitya in Nala and they claim Emperor Ashok had visit to homage Nala Karunamaya. But there is no any traceable evidence when the sculpture of Sristikanta Lokesrow was made.

Buddhists have a great role in making Nepalese culture a glorious one. With the popularity of Buddhism, the images were created in a large number during the then Lichhavi period (Wright, 1877, p.140). Due to the quality of Karuna (compassion) of Lokeswor, they were also called Karunamaya. The emergence of a large number of Lokeswor was accompanied by the development of worship rituals, rituals of fasting and recitation of mantras. In this trend of development, the Newar Buddhists in Kathmandu valley worshipped four prominent Lokesworas. They are Bungadyo or Lokanath of Patan, Adinath (Anandadi Lokeswara) of Chovar at Kachapal parvat, Sristikanta Lokeswara of Nala, and Argyaavalokitesvara of Janbahal, Kathmandu. It is believed these Karunamayas were established in the period of Lichhavi King Narendra Deva in 7th century (Gellner,1996, p.126). The worship of these Lokeswaras has continued since the ancient times. These Lokeswaras have their special virtues of their own. Sristikanta Lokeswara is known for the deed as creator. Bungadyo of Patan is known as harbinger of rain which is indispensable for growing food grains. Adinath Lokeswara of Chovar is known for the virtue of keeping away diseases and improving luck. And Janabahadyo is remembered for the virtue of prolonging longevity of one's life. These four Lokeswaras are specially recognised in the Newar Buddhist culture. In those ancient days job opportunities are limited and so also are the amenities in health and education sectors. Availability of two meals a day, long life, good health, family continuity and discriminative wisdom were recognized as the socio-economic indicators of a successful life and are sought the devotion and religious rituals of the said Bodhisattvas.

\footnotetext{
12 Goddesses reside in ordinary house.

13 The writer could trace only the Bhagawati picture in sword belongs to Hipho caste. Other caste did not tell exactly what they have.
} 
There is a story about the origin of this Karunamaya in Purana ${ }^{14}$. One of the four Karunamayas was $\operatorname{lost}^{15}$ for a long time which was later found in Nala (Wright, 1877 , p.20). The festival of Nala Karunamaya started in 1935 A.D. On the full moon Day of Falgun (March), Nala Karunamaya will be taken out with the ritual of Dasakarmavidhi (ten sacraments) for jatra purpose. The Jatra of Karunamaya Lokeswara is prominent in Nala. By observing jatra, the Nepalese people demonstrated social and religious unity (http://www.aioiyama.net/lrc/papers/cbhnm-ppr-14.htm). The festival of Nala Karunamaya runs for three days during which the deity's idol is given a bath and repainted. On the third day, a grand procession takes place around Nala. The image is carried in a palanquin accompanied by musical bands to the temples of Chandeswori and then brought back to its temple. Pilgrimage and people from Kathmandu and other districts visit Nala to observe the unique culture.

c) Mahalaxmi - Myth says once Nala was subjugated by a ghost and people of Nala were bound to supply sufficient food including a member of family for each night. The ghost used to eat all food including the person who brought the food. This culture was established by the then king (ruler) on rotation basis, one house after the other (family) providing food and a person to the ghost. One day the turn came to a family, who had only couple, husband and wife. On the same night a girl came to their house as a guest. The girl managed to get the permission from family (couple) to take the food for the ghost. On that night the girl was able to kill the ghost and she disappeared. The next day Nala people found the girl was not an ordinary girl and she was Mahalaxmi. From then, people of Nala visit to that house with puja for their prosperity, believing she has visited there. The culture of Mahalaxmi is also popular in Nala.

It is believed the Mahalaxmi (girl) was quite young, then people of Nala worship to Kanya (girl), and organise the Ehee ${ }^{16}$ on the day of Akshatritiya in memory of her victory. Nala community respected other girls and thus the culture of Kanya puja began and Ehee in group treating them as Mahalaxmi goddesses. Girls from community and around the villages will be brought in this ceremony. It is another interesting event to observe, that how they respect to young girl in their society.

There is no temple of Mahalaxmi. The idol of Mahalaxmi is kept in a Dhyo Chhen at Ipa Tole where she had visited as a guest. Mahalaxmi jatra is the main festival of Nala worshiping for wealth and prosperity. The jatra lasts for four days at Nepali New Year eve (April) from the day of Dwitiya 17 of full moon to the day of Panchami. People make a big chariot for Mahlaxmi God and put her into that chariot for four days from Dwitiya

14 The sacred literature of with numbers of popular encyclopedic collections of myths, legends, and genealogies.

15 There is a myth the Sristikanta Lokeswor was stolen by a Tibetean. He could not take beyond Punyamata River then he left the god at the river unattended and people established him in Nala.

16 Ehee, Ihi or Bel Marriage (Nepal Bhasa $O\{x L$ - Bel bibaha) is a ceremony in the Newar community in Nepal in which pre-adolescent girls are 'married' to the bel fruit (wood apple), which is a symbol of the god Vishnu, ensuring that the girl becomes and remains fertile. It is believed that if the girl's husband dies later in her life, she is not considered a widow because she is married to Vishnu, and so already has a husband that believed are still alive

17 Second day of the full moon in the first month of Nepali year. 
to Panchami. First Mahalaxmi is taken to Gopaleswor Dhap ${ }^{18}$ to bath and brought back to bazar and put her into chariot and demonstrate to public and facilitate for local people for pay homage (puja). Similarly, they make chariots for god Narayan and Mahadev. These three chariots with goddess are taken round to Nala on the day of tritiya. This tritiya is known as Akshetritiya, the marriage day of Mahadev and Parvati. People from local area including the Kathmandu valley and Terai also come to Nala to observe this Jatra. Different groups of musical bands devoted to the god and goddess perform music and pilgrimages from different places pay homage Mahalaxmi, Narayan and Mahadev for the prosperity of their life, health and energy. There was a courtesy from Chochhen Tole of Bhaktapur coming with a Naumati musical band in this festival. This could have two purposes one is to get mercy from Mahalaxami goddess and the other is to promote a cultural tourism at neighboring village.

Mahadev Temple - There is a small pagoda type of temple at Tupicha Tole at wards no 3 of VDC. A four headed Shiva lingam is installed in this temple. Temple has four doors but only the west face is open. People use to say this was replica of the Pashupati Nath in Kathmandu.

Gopaleswor Mahadev - As the story say, after the death of Sati Devi (an epic goddess), Mahadev (one of the Hindu trinity) was mad and started travelling here and there carrying the dead body of Sati Devi. One day he reached at Aangal Village and took rest while he was terribly tired. A symbol of Mahadev was appeared at the evening of Dwitiya of full moon in Baishakh (April) where Mahadev was seated. Rishi and Maharshi came to pay homage at symbol and gave the name of Gopaleswor Mahadev. Now, the place is famous with Gopaleswor Mahadev. It is believed that Mahalaxmi has gone to Gopaleswor Dhap to invite Mahadev to participate in Akshatritiya function. Nala people take the Akshetritiya as the day of Shiva and Parvati married day.

Aastha Matrika - Nala was a part of Bhaktapur kingdom and closed to Bhaktapur. People of Nala follow most culture of Bhaktapur, Kathmandu and Lalitpur communities. Bhaktapur kingdom had established the Asthamatrika by Tantrik (Spiritual craft) to strengthen the productivity, empowerment, prosperity and protect them from enemies and epidemic. Such Asthamatrikas were established in Nala by people as in Bhaktapur and other cities under spiritual guidances. The Nala city was surrounded by Asthamatrika as follows;

1. Chamunda Mai at Tushal Village

2. Maheswori Mai at River configuration at Angal Village

3. Kaumari Mai at Ammaldole Village

4. Bramhayani Mai at Dandal Village
5. Mahalaxmi Mai at Thangu (Tapoban)

6. Barahi Mai at Raya Village

7. Vaishnabi Mai at Pande Village

8. Indrayani Mai at Saraswati Dovan (river confegeration)

People of Nala were very happy and well off to afford for relax or enjoyable life. They enjoy their life visiting different goddesses. Nala people visit all the Astha Matrika one

\footnotetext{
18 It is believed that Mahalaxmi went to invite Mahadev and Parvati for Akshatritiya occasion.
} 
by one. They spent 8 days a year in different dates visiting each Astha Matrika. Each family visit the goddess and offered puja and good food and they took back home the same food as offering from the Goddesses. They had made an inn at each Matrika where they could take rest during the puja period.

\section{Cultural Sightseeing}

Nala is properly situated at foot hills with open fertile land to the east, which also provides sufficient heating and light making the place more pleasant. The people of Nala carrying the typical local culture have been maintaining the religious and cultural heritages of their ancestors. The live culture and farming and friendly people are the main resources in the countryside. Following are the some of the religiously and historically important sites of Nala:

Mahadeb Pokhari - Manimaya hill (Tapoban) has a water pound. There was a myth which tells that Mahadev (Shiva) was overnight on the way to Gosaikunda while he was badly suffered from swallowing the Kalkut Bikh (a lethal poison known as Halahala). The Rishi and Muni (Saints) came for meditation (tapasya) where Shiva had taken rest and, they have Darshan (Sight) and, they gave name with Ratna Chundeswor Mahadev. Then the Manimaya Hill called Tapoban. The water pond is known as "Mahadev Pokhari" It is believed that the Rishi, Muni including general people from locality and distance came to pay homage to Mahadev on the full moon day of Bhadra (August) month believing to get the sight of Ratna Chundeswor Mahadev. It is interesting that the devotees from both religions, Hindu and Buddhist participate in that parba (festival). But they have different purpose. Hindu Tagadhari (upper cast) renews their Janai (sacred thread) and Buddhist Lama (Mahayana) pay homage to Shiva and other caste (Matwali) also participate to offer puja to Mahadev and get sacred thread at their hand (Shrestha, 1993, p.9).

Gupha Dole - There is a cave at north of the Nala where Maharsi Balmaki had meditation and this place is known as Gupha Dole. This is situated at just opposite of Brahamayani temple at the river side. It is lovely place where Balmaki wrote some episodes of Ramayan. This place is also known as "Kalam Masi" as people believes Balmaki had made ink and pen to write the Ramayan episode. This is a nice and peaceful hill top that overlooks valley.

Nala Tunnel - There is a tunnel down to the Kalika Forest at the top of Nala bazar. This is situated right to the Ugrachandi at Lagan Tole and left to the Gansa Tole. Every year the Mahalaxmi Jatra ended at the face of this tunnel. There is baked bricks paved about 100 meters at 60 degree slope and the sunlight can easily enter into tunnel as there is no tall houses in front. This tunnel is regarded as a symbol of the development of Nala.

Nala Ban (forest) - The forest of Nala remains still as a good forest for Kathmandu valley. The ceremonial pole for Bisket Jatra of Bhaktapur and Indra Jatra of Kathmandu are selected the tree from Nala forest. The trees are chopped after a puja goat hits it with its head. Bisket jatra in Bhaktapur begins from last week of the twelfth month of the, year as per Nepali calendar. On the day before the New Year (mid April), about eighty feet long huge pole, linga from the Nala Ban will pulled up by hundreds of people to make 
it stand. In Kathmandu, Indra Jatra begins every year from the day of the fortnight Dwadasi of Nepali month of Aswin (September) to the day of Krishna Chaturthi of the next lunar month Ashwin (end of September). It is the eight day long festival. On the first day of Indra Jatra a pole known as Linga or Lyosingh with a flag on the top is made stand at Hanuman Dhoka Choak (Square). This thirty-six feet long wooden pole will choose with great care from the Nala Ban as mentioned before. According to traditional beliefs, Indra had received this flag from Lord Vishnu for protection (Toffin, 1992, p.75).

People of Nala follow all the newari tradition, culture and rituals similar to Bhaktapur apart from major jatras, i.e. Bisket Jatra etc. The cuisines of Nala newar are similar to the other newar's cities in Nepal. The culture of visiting and paying homage to local goddess and annual newari festivals are similar to other newari communities, i.e., Ma ya khou soyagu (mother's day), Digu (family god) puja, Guthi (cooperative), Sithi nakha (special information of starting annual festival), Qyati punhi (beans day), Ba ya Khou soyagu (father's day), Chhotha (Ganesh puja), Gathamo Charhe (Ghanta Karna - killing ghost day), Gulha Chare (information of big festival), Mohni (Dashami), Sunti (Deepawali), Yomari Punhi (special newari dish), Shila charhe (information of ending annual festival) etc.

\section{Livelihoods}

The Kingdom of Ni-po-lo is due west of Tou-fan (Tibet). The father (Udaya Dev) of Na-ling19-ti-po (Narendra Deva) was dethroned by his younger brother (Dhruba Dev); Na-ling-ti-po had to flee to escape from his uncle. Tou-fan gave him refuge and reestablished him on the throne; he consequently became their vassal (Levi,1908, p.69). This demonstrates Narendra Dev was re-established in Nepal from Tibet Empire and Nala could be the point of entry to Nepal (Bhaktapur) and, Nala became one of the trade hubs between Kathmandu Valley and Tibet. This place remained the trade centre for a long time, until the Arnoko Highway started in 1964 AD. So it can simply be guessed that people in Nala must have been involved in trade and business in ancient period.

Nala is famous for 500 Nala 700 Boksi (witch) - A myth says, people of Nala have learned the spiritual-craft from Ugrachandi Bhagawati to overcome from evils and epidemics in those days. A person can gain this skill with a long meditation with following the strict discipline with positive thinking. The men and women having spiritual-craft were/are known as "Tantrik". This became an occupation for their livelihoods. The Tantriks of Nala visit to other communities and villages as healer and varieties of creative work. There were 500 houses in Nala while King Avaya Deva Malla has renovated it in 12th century. It is believed at least a member of family form house acquired the spiritual knowledge/skills for their livelihoods as they could farm through their Tantrik skills. Tantrik Gyan Singh Karmacgharya was famous for completing unbelievable work. Men as well as women have learned the Tantrik knowledge and skills and, the people in other communities were jealous with the intelligence of Nala's women. People from outsider charge them as witch "Boksi" instead of "Tantrik" and blamed the whole Nala as town of Boksi, which sounds injustice indeed. The outside communities whispered each other

19 The name of Nala could from the Tibetan name of Narendra Deva 
saying "500 Nala 700 Boksi", but they could not tell directly to the people from Nala as they do not have any evidence that those women Tantrik misused their Tantras. Tantrism in the time of King Shiva Singh Mall of Bhaktapur at early 16th century was very popular (Shrestha,1972, p.34). The world Boksi is only a nick title given to a weak woman. These days in backward communities the interest group attempted to tag "Boksi" to the poor, helpless vulnerable and single women and they do so for maintaining their superiority in society. The word Boksi is totally against the spirit of Hinduism and Buddhism. Rather it is inhuman and an offence from human rights stand point to tag someone as 'Boksi'.

Bamboo Work - In early days the livelihoods of Pode in Nala depended on fishing in rivers. They also have had the skills of bamboo art, netting basket and other household materials. Nala people believe the material made from the funeral procession will be antievil. They found the bamboo from funeral procession can be recycled for making Kalali (basket) for pilgrimages and Pichha (plate used as net for filtering - used while making local wine - Raksi) for domestic brewery. The art from Pode was found attractive and big demand from neighboring cities and villages, Sanga, Banepa, Khadpu, Chaukot, Dhulikhel, Panauti, Khopasi and Kathmandu valley. The bamboo received from funeral was not sufficient. Then they use other bamboo from Jungle and put a small piece of bamboo in each item ensuring the product making anti-evil. They have improved their skills and start making Dhakki (big plate), Dalo (bucket) etc. from other local materials. It gained a good market, mainly in Bhaktapur and Banepa. Unfortunately, the declining of local raw materials and replacement from plastic and aluminum products, their product lagged far behind in the modern market.

The trade route to Tibet was continued until the motorable linked road made between Banepa to Bhaktapur via Sanga at late 1960s. The trade of Nala declined and people of the town gradually moved towards agriculture occupation. The trade route was completely closed with the completion of Arniko highway in 1970 and the Nala trade confined to local supplies. Employment from agriculture farming was/is seasonal. Most of the town's innovative, creative and traders became unemployed. Consequently, the brain drain started from Nala along with selling of their capital, the land and houses. The household income reduced substantially and could not maintain the socio-economic status. They could not maintain their culture, standardization/maintenance of houses and other infrastructures including the public places, sewage systems and roads. A trail road was opened from Banepa to Nala in 1970s for supplying the agriculture products. Then Nala became famous for supplying the dairy products "Khuwa" (evaporated milk) and potato for Kathmandu valley via Banepa. Nala has demonstrated farming revolution in last few decades. Revolution in farming in the sense that they first increased production of rice, wheat and potato respectively. The production of rice kept the national record in 1963 and wheat in 1973 and potato in 1983.

Despite this prosperous history and great potentiality Nala was doom economically. The state should take care of such things. There was no coordination and cooperation between and amongst leading political parties. This is one of the causes falling down of Nala (Shrestha, 2003, p.33). People of Nala have realised that they have been cheated in democracy where leaders only provided lip service. And these incompetent people remained as peoples' representatives for a long time. The poverty is spread and increased 
with ineffective use of local resources. It is time to revitalize the glory of Nala by regenerating the local energy and resources through promoting countryside tourism.

\section{Heritage Conservation}

Holy River Punyamata at the south of village and the green forest with moderate hills from three corners and the open lightning from the eastern part were the magnetism of growing human settlement of Nala. This town was fabricated with the Lichhavi art depicting the strength of their empire on trade and culture. This town was renovated and expanded in 12th century by Malla Kings by constructing their personal houses with beautiful wooden and stone arts carve in pillars, trusts, window/door with panels. These art works were very prevalent in public buildings. Baked brick, carved stone and paved street were found in the public square etc. The manifestation of those art and cultures signifies the human civilization and economic power of $\mathrm{Nala}^{20}$.

Unfortunately, after the Malla kings were overpowered by the Shahs the later did not give proper attention to the art and culture of Nala as in other parts of Nepal. The local community could not maintain the traditional culture, monuments and art handed by their predecessors as they have to struggle for their livelihood at present. So at present some of the arts and monuments like temples and other infrastructure have been left unaired.

\section{Prospect of Tourism in Nala}

Geographically Nala is situated next to a big Kathmandu valley which was full of water until the water was drained out and the lake turned into fertile land. Nala became a suitable place for meditation to Rishi-Muni (Hermits) and comfortable living location for human settlement. There were good forest and good plain land at Southeast with sufficient natural resources essential for human living in that area. A myth says this place was pilgrimage place for angels from heaven and visiting place for creator god (Shristikanta Lokeswor), the god of superpower (Ugrachandi Bhawagati) and god of prosperity (Mahalaxmi). Nala would be the route to Kathmandu for Hermits and Buddhists (Bipaswi, Bodhisatwa etc.) including the Manjushree along from Tibet for homage to Shining Lotus (Swayambhu) while Kathmandu valley was full of water.

Nala was pilgrimage place for people of Kathmandu valley and neighboring villages, Banepa, Sanga, Khadpu, Chaukot, Panauti, Khopasi and Sankhu visiting goddess residing in Nala. It is believed that the trust upon the goddess increased in Malla period. Mahalaxmi puja and jatra is an attraction for the prosperity of people and country. Nala became more popular for tirthatan (pilgrimage) as one Bhagawati amongst four and one Karunamaya amongst four Karunamaya in Kathmandu valley reside here. In the Malla period Nala was renovated as a new bride. People had added the art in their houses and public places including added festivals in addition to regular Newari culture (festivals in different dates) to attract people from different parts of country. The King residing Bhaktapur encourage devotional musical bands of Bhaktapur to visit Nala in festival days. Among them a

20 Advise to see the video from internet http://www.youtube.com/watch?v=LA9BgPozUtg 
Naumati Baja (Band) from Chochhen Tole of Bhaktapur was continued for the jatra of Mahalaxmi up to last decade as mentioned before.

Different international writers have mentioned about Nala in their book, i.e. Prof. Silva Leve from France has mentioned in History of Nepal, 1908, Lonely Planet etc. This information attracted to the tourist interested on Nala's culture and heritage. In 1980 and 1990s decade the tourist companies in Kathmandu organised a day tour at Nala for international tourist. This was well organised by Yeti Travel of Kathmandu with a coach (big bus) visiting Nala for the day travel. Beside the day tour, this place became famous for trek route from Bhaktapur/Nagarkot to Banepa/Dhulikhel etc. The infrastructure was made with small tea shops, hotels and lodges to attract the international tourist. They have organised community tourism, educating the local Newari culture to national and international tourist. In the event of specific occasion/festival the group tourist were accommodated in individual houses and introduce from preparation to implementation of cultural, i.e. accumulation/collection of goods and items for conducting festivals, participate in cooking special food items and demonstration how to celebrate occasions, i.e Mha Puja, Bhai Tika, Yo Mari Puni, Quati Puni, Sitthi Nakha etc.This was an opportunity to learning food recipe and building spiritual community. It was a good business and both parties were happy and enjoyed with those events. Unfortunately, following the arm insurgency of 1996 the entire tourist activities of Nala was disturb and the hope for Nala's new business of tourism went in vain.

Now, there is an occasional day tourist groups not as in past organised day tour. However, the trekking route is continued and few numbers of tea shops still exist as there are no alternative employments. The tea shops and snack shops suitable only to locals and domestic tourist. The international tourists just take cold drinks, water and hardly take a cup of tea at their visit to Nala. The tourism services in Nala were adversely affected by the armed conflict and it is yet to recover.

People of Nala are aware of international development and role of tourism in contributing social transformation and economic growth. The fund from the guthi (cooperative) and local government is not sufficient for maintaining the cultural heritage of Nala. They had somehow generated some fund for maintaining the local heritage sites mainly through donation to Ugrachandi and Karunamaya from visitors. It was also stopped as the tourist business was disturbed due to the armed conflict. And people with innovative ideas on tourism and the pioneers of tourist business migrated to Kathmandu and other cities during last few decades. It is estimated there are about 1600 houses in Kathmandu of the people migrated from Nala. Now some of them are interested to returning their village for the sake of establishing tourism industry as they have gained experience of tourism business.

As noted earlier Nala is still a famous trekking and bi-cycling tourist route of Nepal traveling from Bhaktapur and Nagarkot to Banepa, Dhulikhel, Panauti and Namobuddha even it has good motorable linked road. It is one of the best countrysides as it is just out of world's second polluted tourist city, Kathmandu and between the two ancient heritage urban centers Bhaktapur and Banepa with beautiful sceneries way tour from Banepa and Bhaktapur. It is linked with many attractive trekking routs as tourist destinations, i.e. Nagarkot, Helambu, Chandeswori, Shilu Mahadevsthan and Dhaneswori with ancient city Banepa, Swet Bhairab with ancient Khandpu and Chaukot settlements, historic 
Panauti city, Dhulikhel town and Khopasi, the industrial city of Kavre District, with international renown tourist centre Namobuddha. Each place above mentioned can be reached by walking tour in a day from Nala. There are neghibouring villages such as Bhandarigaun, Rayagaun, Thakurigaun, Pandegaun, Angal, Tusal, Bule, Kangalgaun, Thapagaun, Dhungakhalgaun, Amaldol, Nayabasti and Sumara in between Nala and famous tourist destination aforementioned. These villages lie approximately in distance of two $\mathrm{km}$. These villages are famous for supplying green vegetables to cities of Kathmandu Valley. Tourist can view the green field and the traditional local farming techniques.

Nala and its neighbouring places are suitable for relaxation with more typical and gratifying life from the suffocating Kathmandu valley. Here people tired of din and bustle of city can have true relaxation and get rid of all stresses of cities. Association with the country life circles around without the amenities such as hot shower, indoor plumbing, a TV and other ties with the world, the countryside tourism usually offer fascinating into natural lull. In Nala and its vicinity area tourist can experience the same country life. Busy people will get an entire package of conveniences plus serenity, incredible beauty of nature, organic food and superb attention from the hosts 21 and sometimes even distractions which are not normally associated with villages. Some countryside is specially created to have minimum comfort, and in spite of that, vacationers swarm to these destinations. The countryside tourist services offer not only full comfort, but is groomed regions with ethnic culture preserving cultural and culinary heritage

The impact of political and economic change on agriculture in the world over the past twenty years has encouraged interest in farm diversification. Leisure and tourism have been prominent in this shift as farms have been converted to tourist accommodation and in some cases to visitor attractions. Tourism is moving from the periphery to the centre of the rural economy and is promoted and encouraged by statutory bodies such as the Department for Environment, Food and Rural Affairs and the Countryside Agency (Bramwell, 1994, p.4). Tourism was growing business after 1965, which drastically increased after 1990. It is unfortunate that this business also declined with the armed conflict of 1996 in Nepal. The decade long armed conflict has a great impact in the countryside of Kathmandu valley and around. The economy was badly affected by migration of human and other resources to urban centres from rural areas. The culture of cooperation and tolerance is deteriorated. Mostly the old people and children were left in villages due to the effect of armed conflict. The situation, to some extent, improved after the political change of 2006 and Constitution Assembly Election of 2008. Even today no conducive environment is made there for the youths to return villages, who migrated to urban centres and overseas in the past. Development of tourism business could create such environment for retaining and returning rural human resources.

Nala have suitable infrastructure for potential tourism business - natural scenery, physical buildings, landscape, cheap human resources and accessibility of communication, transport, financial services, health, etc, required to a tourism industry. Besides, there are sufficient settlements (villages) around Nala which can be used for development of countryside tourism.

21 This will be a closed service from the individual investor or her/his family. 


\section{Conditions for Successful Nala Countryside Tourism Development}

Planning is a multidimensional activity and seeks to be integrative. It embraces social, economic, political, psychological, anthropological and technical factors. It is concerned with the past, present and future. Planning is an intellectual process, the cautious determination of the course of action, leasing decision on purpose, facts and considered estimates. Planning is the function of the managers in which $\mathrm{s} / \mathrm{he}$ decides in advance, what $\mathrm{s} /$ he will do. It is a decision making process in which creation and imaginations are essential. Tourism Planning integrates physical and aesthetic decision of land and structure to the site scale usually carried out by professions of architecture, landscape, interior design and fine arts with social, economic and political actions (Kunwar, 2006, p.252).

The participation of local stakeholders is a key factor in making sustainable tourism development programmes a success. The reason for this is simple, if local people are not involved in tourism development strategies, they can obstruct the development process due to the lack of benefits they will accrue. Without local participation, tourism will fail to realise its full potential as a catalyst for the development of local communities and environments (Dhakal, 2009, p.68).

Local participation is not a one-time activity or event to ensure a project's success that can be checked off before a tourism development project starts. Ideally, it should be a process in which all beneficiaries have an active role in the identification and formulation of problems and opportunities, in the design and implementation of strategies, and in the monitoring and evaluation of results. Participation is intrinsically linked to the project cycle as it incorporates reflection and action and follows all the stages of the cycle from analysis, planning, and implementation to monitoring, based on which plans can be adapted (Dhakal, 2009, p.68).

Several tourism models have been experimented in Nepal, and have had positive as well as negative impacts on the environment and communities. This paper attempts to describe on how to design and establish a countryside tourism business in Nala area. There are a number of critical factors which rural communities must seriously consider when examining the possibilities for countryside tourism in Nala areas. They are; quality tourists wishing a holiday experience; various co-operation groups; a strategic plan; focused marketing; and education and training.

Successful tourism involves getting tourists stayed longer in the area. A countryside area must aim to be a "destination" rather than a place to "stop-off'. Presently Nala is a stop-off for trekkers from Bhaktapur/Nagarkot to Banepa/Dhulikhel. Insufficient facilities, accommodation and attractions in the countryside area lack the ability to draw visitors to it for anything more than a day or a week. It is in the interest of local providers to work together in order to create an environment which can attract quality tourists in the area. It is obvious that local people get economic benefits from longer stays. Communities that have been successful at getting tourists to stay longer, and make them come back can easily developed high quality tourism. Nala has to demonstrate the 5A services if it has to develop as new countryside tourist destination. The table below elaborates $5 \mathrm{~A}$ services. 
Requirements of Countryside Tourism Holiday Network - THE 5 A's (Heneghan, 2002, p.4)

\begin{tabular}{|l|l|l|l|l|}
\hline $\begin{array}{l}\text { Accommodation } \\
\text { Base }\end{array}$ & Access Facilities & Available Services & Amenities & Activities \\
\hline Lodge & Airport & Bank & Scenery & $\begin{array}{l}\text { Mingle in } \\
\text { Cultural }\end{array}$ \\
\hline B \& B & $\begin{array}{l}\text { Surface travel } \\
\text { Road })\end{array}$ & Taxi & Landscape & Pubs \\
\hline Home Stay & $\begin{array}{l}\text { Booking and } \\
\text { reservation }\end{array}$ & $\begin{array}{l}\text { Car /Motor bike } \\
\text { Hire }\end{array}$ & Himalayas & Volunteerism \\
\hline Self Catering & $\begin{array}{l}\text { Modern } \\
\text { Communication }\end{array}$ & Mountain bike hire & Mountain & Walks/Trek \\
\hline Small Hotels & Travel Trade & $\begin{array}{l}\text { Entertainment } \\
\text { (Theatre })\end{array}$ & Forest Rivers & Fishing \\
\hline Hotel & Logistic Service & Catering & Garden & Sports \\
\hline Camp Site & Other Facilities & Restaurant & & Agri Farming \\
\hline Caravan Sites & & Shops & Heritage site \\
\hline
\end{tabular}

Co-operation between and amongst countryside tourism service providers, business people and community activists who understand the benefit from tourism in the area is important. Networking and co-operation allows; quality in tourism services; maximisation of pool resources; reduce marketing costs; set up partnerships with government agencies for training, promotion, support and funding; draw up strategic plans for tourism in the area; increase their knowledge base; lobby for support; develop community resources for tourism such as walks, heritage projects, fishing, agrifarming, volunteerism (paid/unpaid), environmental projects, agrifarming and participate in local cultural etc. and strength in numbers.

Sustainability is one of the development processes. The concept has been dealt with by several scholars and the term "development" is used in everyday contexts; people speak of the development of an individual, an organisation, a place and society as a whole. There are three important aspects of sustainability: ecological sustainability, social culture sustainability and economic sustainability. Ecological Sustainability ensures that development is compatible with the maintenance of essential ecological process, biological diversity and biological resources. Social cultural sustainability ensures that development increases people's control over their lives is compatible with the culture and values of people affected by it and maintains and strengthens community identity. Economic sustainability ensures that development is economically efficient and that resources are managed so that they can support future generation (Kunwar, 2006, p.193).

Co-operative effort must be effective and sustainable in this business. There are numbers of cooperatives in Nala and they have sufficient financial resources. Two sets of expectations exist within Nala community - one set of needs/expectations comes from 
community activists whose expectation of the initiative is development. Therefore they want to concentrate on product and development for tourism in the locality. The second set of needs/ expectations comes from tourism providers who want tangible benefits in the form of improved results from marketing efforts. There are clearly two separate but closely linked functions which the group is expected to fulfill, they are; Development Function and Marketing Function.

The tendency within Nala countryside tourism groups is to spend more time on development and promotion, at establishment when marketing needs, in the form of increased sales. Failure to develop each with parallel strategies for both functions impedes the long term success of the group.

Development Function - This element of the project should undertaken by local community activists to include tourist interests, providers, historians, geologists, environmentalists, anglers, farmers, publications and shopkeepers in the locality who see potential for tourism development in the area. It is vital to develop local leadership skills at this stage. With a development focus, the groups will able to concentrate on identifying local resources such as heritage, rivers, eco and environmental tourist services and activities and establish their development potential, source of finance for development

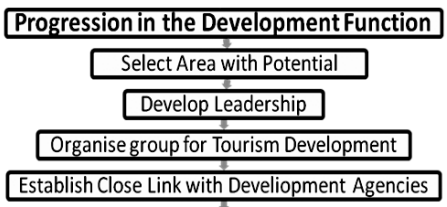

Conduct Resource Audit for Tourism using 5A's Guidelines

Analyse Resources Audit and Select / Priorities Areas for Development

$$
\begin{aligned}
& \text { Set Vision } \\
& \text { Identify an Image for the Locality }
\end{aligned}
$$

Draw up a Development Plan for Each Product and Cost it

in Co-operation with Specific Interest and Agencies

Liaise with bodies \& Agencies for Assistance

Liaise with Marketing Initiatives and set up partnership with agencies and bodies who can be of assistance (Heneghan, 2002, p.5). The flow chart at the opposite of this text summarizes the development function.

Marketing Function - A separate marketing function focusing only on the tasks of marketing is required. This function

\section{Progress in the Marketing Function}

Establish Aims / Goals and Set Targets

Organise Group for Marketing

Set up Partnership with Marketing Agencies and Get Clear Understanding of roles of Agencies and Linkage with Tourist Trade. Prepare a draft Plan

Best Method for Promotion and Selling Set up System for Sales

$\begin{gathered}\text { Prepare Portfolio of Products, Prepare Promotional Materials, } \\ \text { Establish Holiday Package Locally }\end{gathered}$
Research Packages with Market
Adjust Packages
Identify a Sales Person, Put a Marketing Plan in a Place
Set up Sales Facilities
Network with Other Tourist Initiatives
Assess Marketing Strategies against Sales
will have close links with the development function but will be separate and independent, for example, assessing what the market requires, providing holiday packages, preparing marketing literature and promotional materials and facilitating sales. The marketing function requires people with business and marketing skills, capable of drawing up marketing strategies, measurable by occupancy levels, preparing holiday package unique to the locality and tailoring packages to suit customer needs (Heneghan, 2002, p.6). The flow chart opposite to this text summarizes the marketing function. 


\section{The Countryside Tourism Product}

The diagram below presents relationship between the different elements that make up the countryside tourism product and impact (Knowd, 2001, p.25).

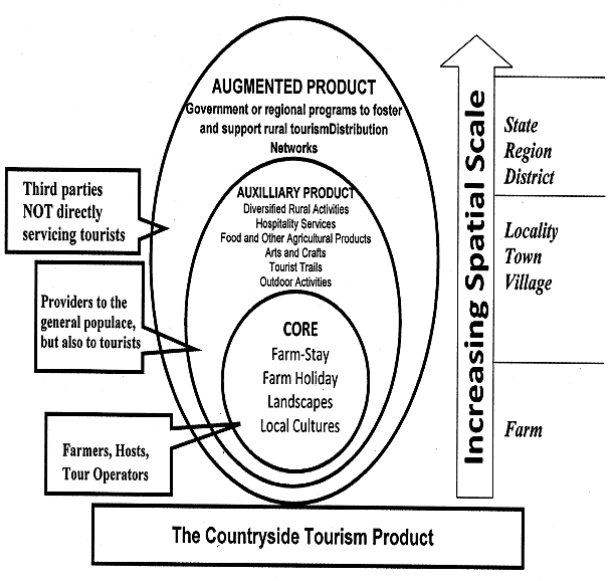

Core product is understood to be the actual experiences that tourists want to have in village/rural contexts. These experiences are on-site experiences which provide the opportunity to share the culture and countryside living within a natural landscape.

Auxiliary products are those that tourists would like to have as part of their experience, but are not essential to the product. Their role is in core product enhancement will include such things as countryside museums and galleries, the hospitality services tourists receive whilst visiting a countryside, participating in outdoor activities, arts and crafts, and touring on "tourist trails".

Augmented product represents all the other benefits tourists receive whilst consuming the countryside tourism product that facilitate their consumption. This includes such things as improved amenities and public infrastructure facilities in countryside, interpretive signs, visitor centers and information booths, state sponsored promotion and information distribution, improved access via sign-posting, roadwork or other transport facilitation projects.

Thus the countryside tourism should be developed with suitable accommodation, friendly people and scenic beauty historical and cultural attractions, rest and relaxation. On the other hand, the attraction of natural beauties may be something that cannot be charged (e.g.; scenery) and this will derive income from the value-adding. These descriptions fall well short of actually shedding light on what countryside tourism really is.

\section{Conclusion}

Nala is full of ample potentialities which can contribute to develop it as a countryside tourist destination. Natural scenery, cheap labour and human resources, its closeness to capital city of Nepal, being heritage sites, availability of ruins, sufficient space to accommodate varieties of visitors with their special activities - relaxation, day tour, conducting events etc. are, without any doubt, all the resources of Nala. Besides, Nala has tourist products such as handicrafts, typical food, etc. Nala can engage the tourists by providing space for agri-farming so that they will have opportunity to have organic product and fishing as well. Cheap tour guide and homely atmosphere for short staying are also other attractions. Sharing knowledge and skills on human development in countryside of Nepal can be an academic activity in this historical town. 
It is evident that Nepal is famous for tourism in the world for both its natural beauty and diverse cultural heritages. Mount Everest, the highest peak in the world and Lumbini, the birth place of Buddha are not only the natural and cultural heritage of Nepal but also of the entire world. Though Nepal has numerous natural beauties, it has not taken advantage of them yet due to lack of proper policy and promotion strategy. The data shows that the national income from tourism is less that $2 \%$. Nepal is full of villages and income of village can only contribute in national income if their potentiality is optimally used by promoting resources. Presently, the tourist stay in Nepal is average 12 days, which can be extended with the development of rural and countryside tourism. Nala will be representative countryside tourism. Mainly Countryside can extend the tourist stay and open avenues for exchange of technology between host and guest as they will stay longer and work closely with host. Nala can be an exemplary countryside tourist destination which has all required conditions and it can be done with minimum investment.

To obtain the above goal of promoting countryside tourism it requires pragmatic policy, institutional and individual commitment and investment. Nala has these capacities with the numbers of functional cooperatives. In addition, there are many competent individuals and family who migrated from Nala after the armed insurgency of 1996 and at present they would like to return their motherland. This will be an ample opportunity to the cooperatives, organisation, individual and family to contribute with the mutual benefits for their future.

The range of cultural activity beside agrifarming and trek routes in Nala is quite endless entirely depending on the inclination and time at tourist disposal, where they can make number of day tours testing the natural beauties and seasonal agritourism enjoying periodic cultural events. It is a high time for systemic developing country-side tourism in Nala and this is an opportunity to use the resources of local governments and Nepal Tourism Board (NTB) to demonstrate their competency in country-side tourism development of Nepal.

\section{Reference}

Aryal, K. (2004). Influence of Hindu Religion in Framing of Nepalese Legal System, Unpublished L.L.M. Thesis, Kathmandu: Kathmandu School of Law.

Bajracharya, R.K., Shrestha, R.P., Dahal, S.P., Pathak, G.N., (Eds.). (1997). Pradipika, Special Publication on Golden Jubilee of Nala: Chandeswori Secondary School.

Bajracharya, S.B. (2009). Tourism Development in Annapurna Conservation Area. In: Kruk, E., Kreutzmann, H. and Richter, J., (Eds.). Integrated Tourism Concepts to Contribute to Sustainable Mountain Development in Nepal, Kathmandu: GIZ: ICIMOD and MBZ.

Bajrachaya, D. (1970). Defense Arrangements During The Mall Period And The Obligations of The Subjects. In Regmi, M. C., (Ed.). Regmi Research Series, Kathmandu $2(5), 110-113$.

Barahi, S., Fan, R., Hung, P., Malla, P. and Yeung, R. (Eds.). (2011), Tourism Cluster 
66 Journal of Tourism and Hospitality (Vol. 5)

in Nepal, Microeconomics of Competitiveness, Cambridge MA: Harvard Kennedy School.

Bill, T. (2005). Community-Based Tourism in Lao DPR: An Overview http://www.nafri. org.la/document/sourcebook/Sourcebook_eng/Volume1/25_cbtppp_rdma.pdf

Bramwell, B. and Lane, B. (Eds.) (1994). "Rural tourism and sustainable rural development", Proceedings of the Second International School on Rural Development 28 June - 9 July 1993, University College, Galway, Ireland. Clevedon: Channel View Publications.

Chitrakar, A. (2006). Bhagawati, ESC Nepal, May 2006, Kathmandu: ESC Media.

Christian, K.F., Hering, D. and Moog, O. (Eds.). (2005). Development of an Assessment System to Evaluate the Ecological Status of Rivers in the Hindu Kush - Himalayan Region, Vienna, University of Natural Resources and Applied Life Science.

Dhakal, D.P. (2009). Tourism Development and Its Impact. In: Kruk, E., Kreutzmann, H. and Richter, J., (Eds.). Integrated Tourism Concepts to Contribute to Sustainable Mountain Development in Nepal, Kathmandu: GIZ: ICIMOD and MBZ.

Gellner, D.N. (1996). A Sketch of the History of Lalitpur (Patan) with special Reference to Buddhism. Contribution to Nepalese Studies, Kathmandu: CNAS 23 (1), 125-157.

Heneghan, M. (2002). Structures and Process in Rural Tourism. Teagasc: Irish Agriculture and Food Development Authority.

Kanel, C.N. (2009). Community-Based Rural Tourism in Ghalegaon, Lamjung, Nepal: A Case Study. In: Kruk, E., Kreutzmann, H. and Richter, J., (Eds.). Integrated Tourism Concepts to Contribute to Sustainable Mountain Development in Nepal, Kathmandu: GIZ: ICIMOD and MBZ.

Karmacharya, S., (2003). Etihasik ra Puratawtik Mahatwa Bokeko Nala Sahar. Shrestha, R.P.A., (Ed.). Nala Samaj Smarika. Nala: Anamani Publisher.

Khatri, L.B., Kayastha, R.P., Khatri Chhetri, J. and Madan, P.P. (Eds.). (2012). Nepal Tourism Stastistics 2011: Annual Statistical Report. Kathmandu: Ministry of Culture Tourism and Civil Aviation.

Knowd, I. (1998). Rural Tourism: Panacea and Paradox. School of Environment and Agriculture, University of Western Sydney.

Kunwar, R. R. (1997). Tourism and Development: science and industry interface. Kathmandu: Laxmi Kunwar.

Kunwar, R.R. (2006). Tourists and Tourism: Science and Industry Interface. Kathmandu: IST.

Levi, S. (1908). Farliest References to Nepal: Epigraphic and Literary Evidence. Legendary Origin of the Name of Nepal.. Translated by Theodore Ricaardi Jr. (Ed.), The History of Nepal Part I Kathmandu: Kailash - Journal of Himalayan Studies, Ratna Pustak Bhandar (1975), 3 (1), 4-60.

Levi, S. (1908). Nepal (Continued) II Chinese and Tibetan Document. Translated by Theodore Ricaardi Jr.(Ed.). Ancient Nepal, Department of Archaeology (1974) (27), 63-80. 
Littleton, S. and Allcock, A. (2002) Tourism as a Tool for Development. External Review. UNESCO - Lao National Tourism Authority, Nam Ha Ecotourism Project.

MAF (1994). Thinking of Starting in Rural Tourism?: A Resource Book, New Zealand: Ministry for Agriculture and Fisheries.

Mohammad, E. A. and Zahra, R. (n.d.). Culture and its role in tourism development. Life Sci J 2012;9 (3):1593-1597] (ISSN:1097-8135). http://www.lifesciencesite.com

MoTCA (2009). Tourism Vision 2020. Kathmandu: Ministry of Tourism and Civil Aviation.

National Delphi Study (2000). National Delphi Study on Public Health Function in Australia: Reports on Findings Introduction. http://www.dhs.vie.gov.au/nphp/ppi/ corefune/delphi/intro.htm (accessed Sept 26,2002)

Owens, B.M. (1993). Bloods and Bodhisattvas: Sacrificing Amongst the Newar Buddhist of Nepal. http://college.holycross.edu/projects/himalayan_cultures/2011_plans/jclossic/ documents/blood.pdf.

Gyawali, S.B. (1971). Malla Kingdom of Kathmandu. In: Regmi, M. C., (Ed.). Kathmandu: Regmi Research Series, 3 (11), 251-260.

Regmi, D.R. (1983). Inscription of Ancient Nepal Volume I, New Delhi: Shakti Malik, Abhinav Publication.

Sharma, S., Bhattarai, U. (2009). Nepal's Approach to Tourism Development. In: Kruk, E., Kreutzmann, H. and Richter, J., (Eds.). Integrated Tourism Concepts to Contribute to Sustainable Mountain Development in Nepal. Kathmandu: GIZ: ICIMOD and MBZ.

Shrestha, R.P.A. (2012). Ugrachandi Nala Ko Avilekh Sangraha. part one, Nala: Anamani Publisher.

Shreatha, G and Shrestha, J. (1993). Introduction of Nala. , Kathmandu: Jivan Printing Press.

Shrestha, A. (2009). Ghandruak Nepal. Sustainable Village - 50 Years Planning. unpublished, Batchlor Dissertation, Saint Louis University.

Shrestha, D. B. and Singh, C.B. (1972). The History of Ancient and Medieval Nepal. Kathmandu: HMGN Press.

Shrestha, H. D. (2003). Guphadole: Ek Chinari, Nalako Samanya Parichaya. Shrestha, R.P.A., (Ed.) Nala Samaj Smarika. Nala: Anamani Publisher.

Shrestha, R. K. (2003). Nala Desh Ko Aabastha and Hamro Daitwa. Shrestha R.P.A., (Ed.). Nala Samaj Smarika. Nala: Anamani Publisher.

Shrestha, R. (2003). Nalako Samanya Parichaya. Shrestha, R.P.A., (Ed.) Nala Samaj Smarika. Nala: Anamani Publisher.

Taylor, R.E. (1992). Pros and Cons of the Delphi Technique and Suggested Relationship to Management Science. Decision Science in the Public Sector. North Whitefield, ME: Felicity Press. 
Toffin, G. (1992). The Indra Jatra of Kathmandu as Royal Festival. Contributions to Nepalese Studies. Kathmandu. CNAS 19 (1), 73-92.

.... (2012). United Nation Tourism Highlights 2012. www.unwto.org/pub

..... (2001). Working for the Countryside. A strategy Rural Tourism in England 20012005. London: English Tourism Council.

(2007). Study on Role of Tourism in Socio-Economic Development, Economic and Social Commission for Asia and Pacific (ESCAP), United Nation, New York.

Wall, G. (1993). Towards a Tourism Typology. In Nelson, J.G., Butler, R. and Wall, G. (Eds). Tourism and Sustainable Development: Monitoring, Planning, Managing. Waterloo, Canada: Heritage Resources Centre Joint Publication No 1, Department of Geography, University of Waterloo.

Wright, D. (1877). History of Nepal. New Delhi: Asian Education Service.

www.world-tourism.org

www.tourism.gov.np

www.ntb.org.np

www.natta.org.np

http://www.ntnc.org.np

http://www.tdbl.com.np/content/welcome-to-tourism-development-bank.html

http://www.holidayworld.com.np/index_festival.php

http://ne.wikipedia.org/w/index.php?title=pu|r08L_gfnf\&oldid=274581

http://www.aioiyama.net/lrc/papers/cbhnm-ppr-14.htm

http:/www.priceoftravel.com/2060/asia-backpacker-index

http://www.youtube.com/watch?v=VnKxAJYBCos

http://www.youtube.com/watch?v=LA9BgPozUtg

http://en.wikipedia.org/wiki/Samudra_manthan 